\title{
Chapter 9 \\ The Growth of Ethnic Minorities in Uruguay: Ethnic Renewal or Measurement Problems?
}

\author{
Wanda Cabella and Rafael Porzecanski
}

\subsection{Introduction}

Racial and ethnic identities constitute one of the most important sources of inequality and social solidarity in the Americas. Although race and ethnicity have a notable social impact, it is not easy to produce reliable ethno-racial statistics. This is especially true for the Latin American region, where ethnic and racial identities are more fluid, contextual and unstable than in the U.S. Several studies show that racial statistics vary substantially according to the specific methodological devices used to measure race. In Brazil, for instance, Telles and Lim (1998) show that racial inequality is higher when the race variable is constructed according to the interviewers' perceptions of the respondents' race than when race is measured through respondents' self-classification. In Colombia, in turn, while Afro-descendants were $1.5 \%$ of the total population according to the 1993 Census, they were $9.8 \%$ according to the National Household Survey of 2004 (Urrea 2005). This substantial difference is probably explained by the different dimensions of race captured by each survey question. While the 1993 census asked individuals if they were members of an Afrodescendant community, the 2004 survey asked them if according to their physical characteristics they were black, white, mestizos or mulattos.

This chapter presents an analysis of racial classification in Uruguay, a South American country that has been rarely mentioned in studies of ethnic and race relations. The main goal of the chapter is to analyze the statistical growth of the Afro-descendant and indigenous populations during the last decade. According to

\footnotetext{
W. Cabella $(\bowtie)$

Facultad de Ciencias Sociales, Universidad de la República, Montevideo, Uruguay

e-mail: wanda.cabella@cienciassociales.edu.uy

R. Porzecanski

Montevideo, Uruguay

e-mail: rporze@netgate.com.uy 
the Encuesta Continua de Hogares of 1996-1997 (hereafter ECH) and the Encuesta Nacional de Hogares Ampliada of 2006 (hereafter ENHA) carried out by the National Institute of Statistics (INE), the Afro-descendant population increased 7.4 points (from 1.7 to $9.1 \%$ ) while the indigenous population jumped from 0.8 to $3.8 \%{ }^{1}$

The chapter discusses two major possible interpretations of this remarkable trend. First, we suggest that this growth reflects the effects of the different methodological devices used to measure race in each of these surveys. Another plausible explanation points to the increasing social legitimacy of non-white identities, as the consequence of higher levels of mobilization of local and regional indigenous and Afro-descendant organizations. The chapter ends with a discussion of the extent to which changes of racial classification and measurement have affected the indices of racial inequality in the country.

\subsection{Ethnic and Race Relations in Uruguay}

In contrast to the majority of its Latin American neighbours, the Uruguayan population is mainly composed of European descendants from Spain and Italy. In 1860 the national population barely exceeded 200,000 persons and the proportion of foreign born residents was $34 \%$ (mainly Spanish settlers). During the last decades of the nineteenth century, Uruguay became an important destiny of overseas migration. The 1908 census counted more than one million people. The remarkable population growth reflected in that census was mainly explained by the abovementioned arrival of significant numbers of immigrants (Pellegrino 2003). The arrival of large numbers of Europeans continued until the 1940s. Since then, Uruguay has not received significant numbers of immigrants and, in contrast, thousands of Uruguayans have left the country in search for better economic opportunities.

Although the majority of Uruguayans are European descendants (especially Spaniards and Italians), there is a non-negligible percentage of the population who is of African descent. The origins of the Afro-Uruguayan population date back to the first decades of the seventeenth century when the first waves of slave labour were smuggled into the country (by then called the 'Banda Oriental') through contraband. ${ }^{2}$ Most of the African population, however, was imported legally between 1742 and 1810 under Spanish rule (Rodríguez 2006). During that period, recent

\footnotetext{
${ }^{1}$ The Permanent Household Survey is the country's main source of annual information on labour market indicators. It is conducted all over the year and based on big samples. The 2006 version constitutes a special case, for it was implemented among a particularly big sample size (approximately 257,000 individuals), collected data on a multiplicity of topics (such as health and migration) and reached the population living in cities of less than 5,000 residents and rural areas.

${ }^{2}$ Although significant numbers of Afro-descendants were brought to the country as slaves during the seventeenth and eighteenth centuries, the importation of slaves was less important than in countries such as Brazil, Colombia and Ecuador, where high numbers of labourers were required for large-scale plantations and mining.
} 
historiography estimates that an average of four ships of slaves arrived to the port of Montevideo annually and that between 33,000 and 45,000 slaves entered the country (Montaño 2001; Frega et al. 2005). ${ }^{3}$ In 1819, slaves constituted approximately $25 \%$ of the total population of Montevideo. The proportion of Afro-descendants would diminish throughout the country's history as the combined result of large immigrant flows from Europe, wars, diseases and miscegenation. ${ }^{4}$

With reference to indigenous groups, before the Spanish conquest, demographically small indigenous communities such as the Charruas, Chanas and Guaranies populated the Uruguayan territory. These groups gradually disappeared as a consequence of a variety of diseases, wars and extermination campaigns (Bracco 2004). Thus, today Uruguay does not have indigenous communities with their own language, cultural traits and organizational apparatus. However, as we will show below, $3.8 \%$ of Uruguayans declared being of indigenous descent in the ENHA of 2006. In addition, there are a growing number of local indigenous organizations that fight for the official acknowledgment of the indigenous contributions to the country's history and culture.

The predominance of a population of European descent and the national state efforts of constructing a highly integrated society helped foster the national myths of racial democracy, homogeneity and equality of opportunities (Arocena and Aguiar 2007). ${ }^{5}$ These myths have been largely accepted by the majority of Uruguayans throughout the country's modern history. Only at the end of the twentieth century, research contributions from disciplines such as history, anthropology and archaeology will question these myths by showing that ethnic minorities played a higher role in Uruguayan history than that attributed by the dominant intellectual and political perspectives (Cabrera and Curbelo 1988; Sans et al. 1997).

\footnotetext{
${ }^{3}$ Not all these slaves, however, remained in the Uruguayan territory. Some of them were sent to other regional domains of the Spanish Empire.

${ }^{4}$ The first steps towards the abolition of slavery were taken in 1814 by the independentist government of Jose Artigas through the declaration of 'freedom of wombs' (children of slave descent). The Portuguese Empire, however, revoked this measure when it defeated the Artiguista government in 1817 and governed the country for more than a decade. After the achievement of independence in 1828 , slavery was gradually eliminated, first by decreeing the 'freedom of wombs' and declaring slave traffic illegal, later by abolishing slavery and finally by eliminating the juridical figure of 'patronato' in 1853. In congruence with the historical absence of overt forms of official segregation and discrimination, the evolution of the Afro-Uruguayan community is characterized by increasing degrees of integration or assimilation in multiple dimensions.

${ }^{5}$ After the abolition of slavery in 1852 , all Uruguayan citizens have been considered equal under the law and the only requisites to obtain full Uruguayan citizenship rights have been to be born in the country's territory or, alternatively, to have a Uruguayan father or mother (voting rights, however, remained limited for a significant sector of the population, especially women, until 1932). Like in the vast majority of Latin American countries, thus, in modern Uruguay race has not constituted a criterion for the distribution and allocation of state resources, rights and obligations among the population.
} 


\subsection{Ethnic and Racial Identifications According to the Encuesta Continua de Hogares}

\subsubsection{The ECH of 1996-1997}

Unlike regional cases such as Colombia, Brazil, Peru or Bolivia, studies on the socioeconomic and demographic situation of the Uruguayan population have rarely taken into account ethnic or racial variables. Indeed, a comprehensive literature review reveals that among the thousands of anthropological, sociological or historical works published on the Uruguayan population, only a very small minority focuses on ethnic or racial topics. The fact that official surveys or censuses did not collect data on race or ethnicity until the end of the twentieth century, together with the abovementioned national myths of racial homogeneity and democracy, probably explains the remarkable dearth of social scientific analysis of ethno-racial minorities.

Responding to the pressure exerted by Afro-Uruguayan organizations and international agencies, the National Institute of Statistics (INE) included a race question in the Permanent Household Surveys of 1996 and 1997 for the first time in the country's history $^{6}$. The ECH of 1996-1997 collected data on race through the following question: 'What race do you think you belong to?' Respondents were permitted to classify into only one of the following categories: 'Amarilla' (Yellow); 'Negra' (Black); 'Blanca' (White); 'Indígena' (Indigenous) and 'Mestiza' (Mixed). ${ }^{7}$ To those who responded 'Mestiza' the following question was also asked: 'Of what races do you think you have blood?' enabling the respondent to choose more than one racial category but only among the abovementioned options. The 1996 survey also asked about parental race to those household members who were interviewed, using again the abovementioned five racial categories (this question, however, was not applied in the 1997 questionnaire).

As we can observe in Table 9.1, the great majority of the population chose the white category, followed by the mestizo, black, yellow and indigenous categories respectively. The significant percentage of missing data responds to two factors. First, due to processing problems, INE lost the information on race for 6,392 cases. Also, there were 12,248 interviewees who refused to answer the racial question or did not choose any of the categories available.

As abovementioned, those who chose the mestizo category were asked if they had black, white, yellow, indigenous or simply mestizo blood. In Table 9.2 we show that approximately $40 \%$ of mestizos indicated that they had white blood, $19 \%$ that they had black blood, $12 \%$ that they had indigenous blood and a negligible proportion self-identified as mestizos with yellow blood. It is interesting to observe that a high

\footnotetext{
${ }^{6}$ Originally, INE planned to collect data on race only in 1996. However, the number of respondents who self-classified as non-white was too small to obtain reliable estimates. INE therefore decided to apply the race question in 1997 too.

${ }^{7}$ It is worth noting that, like most regional surveys, the ECH captures racial identity through a combination of self and external classification, for those household members who respond the questionnaire (the household head or another adult member) are asked to classify the rest of noninterviewed members.
} 
Table 9.1 Racial classification in Uruguay (1996-1997)

\begin{tabular}{l|r|r}
\hline $\begin{array}{l}\text { What race do you think you } \\
\text { belong to? }\end{array}$ & \multicolumn{1}{|c}{$\%$} & $\%^{\mathrm{a}}$ \\
\hline White & 80.8 & 94.2 \\
\hline Black & 0.8 & 0.9 \\
\hline Indigenous & 0.2 & 0.2 \\
\hline Yellow & 0.3 & 0.4 \\
\hline Mestizo & 3.6 & 4.3 \\
\hline Missing data & 14.3 & \\
\hline Total & 100.0 & 100.0 \\
\hline
\end{tabular}

Source: ECH 1996-1997 (N=128,722)

${ }^{a}$ Without missing data

Table 9.2 Ethnic - racial identification of Uruguayan Mestizos (1996-1997)

\begin{tabular}{l|l|l|l}
\hline "Of what races do you think you have blood?" & Yes & No & Total \\
\hline White blood? & 42.6 & 57.4 & 100 \\
\hline Black blood? & 18.6 & 81.4 & 100 \\
\hline Indigenous blood? & 12.4 & 87.6 & 100 \\
\hline Yellow blood? & 0.6 & 99.4 & 100 \\
\hline
\end{tabular}

Source: ECH 1996-1997

percentage of mestizos (51\%) did not recognize having black, indigenous, yellow or white blood. This finding is somewhat puzzling if we bear in mind that there are no other significant racial groups in the country. It seems sound to hypothesize that these mestizos do not perceive themselves as strictly whites (based on physical traits) but that, at the same time, they cannot specify the racial components of their mestizo condition. This is not surprising if we take into account that, in congruence with the wide acceptance of the national myths of racial homogeneity and democracy, racial identities are not frequently activated in Uruguayan everyday life.

It must also be noted that our classification differs substantially from that elaborated by INE. While INE estimated that there were $5.9 \%$ of Afro-descendants in 1996-1997 (Beltrami 1998), we estimate that Afro-descendants were $1.7 \%$ of the population $(0.9 \%$ of subjects who identified as racially black and another $0.8 \%$ who chose the mestizo category and declared having black blood). ${ }^{8}$ The main factor that explains the substantial differences between INE and the authors' data is the differential treatment of mestizos for which no additional racial data was available. Unlike the authors, INE decided to classify the population identified as 'mestiza' into one of the other racial categories based on additional information such as parental race. Also, INE imputed the race of the population with missing data based on a number of statistical procedures (INE 1998). As a result of this, INE ended up

\footnotetext{
${ }^{8}$ The only official publication that discusses the racial composition of the Uruguayan population using the 1996 survey does not provide details on the processes through which INE re-classified the race of mestizos and imputed the race of those cases with missing data (Beltrami 1998). INE provides these details in an unpublished manuscript which is available at request.
} 
Table 9.3 Main descent of Uruguayan Mestizos (1996-1997)

\begin{tabular}{l|r}
\hline Descent & \multicolumn{1}{l}{} \\
\hline White \& Mestizo & 15.7 \\
\hline White \& Black & 14.5 \\
\hline White \& Indigenous & 10.7 \\
\hline Black \& Mestizo & 2.6 \\
\hline Black \& Indigenous & 0.2 \\
\hline Indigenous \& Mestizo & 0.6 \\
\hline Mestizo & 50.9 \\
\hline Other combinations & 4.8 \\
\hline Total & 100
\end{tabular}

Source: ECH 1996-1997

${ }^{a}$ Mestizos who declared not having white, black, indigenous or yellow blood

Table 9.4 Racial classification in Uruguay (2006)

\begin{tabular}{l|l|l|l}
\hline Do you think you are of...?: & Yes & No & Total \\
\hline White descent & 96.9 & 3.1 & 100 \\
\hline Black descent & 9.1 & 90.9 & 100 \\
\hline Indigenous descent & 3.8 & 96.2 & 100 \\
\hline Yellow descent & 0.3 & 99.7 & 100 \\
\hline
\end{tabular}

Source: ENHA 2006

treating the overwhelming majority of these mestizos as 'blacks', probably based on the assumption that the Afro-Uruguayan population is more significant than the Indigenous and Asian population. We, however, did not adopt this decision and preferred to treat this subgroup simply as mestizos (Table 9.3). ${ }^{9}$

\subsubsection{The ENHA of 2006}

In 2006, the race question changed significantly and respondents were asked if they believed to be of Afro/black, white, yellow or indigenous descent in separate questions. All respondents thus, were given the possibility of selecting more than one option. No questions on parental race, in turn, were asked in this occasion even though it is possible to know parental race for subjects who reside in the same household than their parents. As we can observe in Table 9.4, the great majority of

\footnotetext{
${ }^{9}$ In the majority of Latin American countries, the mestizo term is associated with the possession of both white and indigenous ancestors or phenotypic markers. In accordance with the small weight of indigenous groups this term is not popular in Uruguay. Therefore, it is not straightforward to infer who picked up the mestizo category in the $\mathrm{ECH}$ of 1996 . Were mestizo respondents mainly subjects who believed being of indigenous and white descent or, alternatively, subjects who believed being of African or other types of descent? Although INE decided to treat mestizos with no additional information as blacks, we believe that the safest methodological procedure is to treat them simply as mestizos until further evidence suggests the implementation of alternative criteria.
} 
Table 9.5 Main combinations of ethnic-racial descent in Uruguay (2006)

\begin{tabular}{l|c}
\hline Descent & $\%$ \\
\hline Only White descent & 87.4 \\
\hline White - Black descent & 6.3 \\
\hline White - Indigenous descent & 2.5 \\
\hline White - Yellow descent & 0.1 \\
\hline Only Black descent & 2.0 \\
\hline Black - Indigenous descent & 0.2 \\
\hline Only Indigenous descent & 0.4 \\
\hline Only Yellow descent & 0.1 \\
\hline Other combinations & 1.2 \\
\hline Total & 100 \\
\hline
\end{tabular}

Source: ENHA 2006; N=256,866

the population declared being of white descent, in accordance with the predominance of Uruguayans of European background. Also, as we see in Table 9.5, around $87 \%$ of the population declared being of white descent exclusively. This suggests that the great majority of Uruguayans believes that all their significant ancestors are from European countries.

A significant proportion of the population, however, declared having black and/or indigenous ancestry $(9.1 \%$ and $3.8 \%$ respectively). It is interesting to observe that most of those who recognized having these racial backgrounds also declared being of white descent. For instance, $6.3 \%$ of the population declared being of white and black descent, while $2.0 \%$ declared being of black descent only. Similarly, $0.4 \%$ of the population identified as indigenous only while $2.5 \%$ declared having indigenous and white ancestry. Thus, the data indicate that the process of ethno-racial miscegenation has been important in the country and that only small proportions of the country's ethno-racial minorities did not mix with the dominant Euro-descendant population.

Finally, unlike the ECH of 1996, a very small number of interviewees refused to answer the racial question in 2006. This suggests that the classification criteria used in the last survey was much better understood and provoked lesser degrees of resistance than that applied in the 1996 edition.

\subsection{Comparing the Household Surveys of 1996 and 2006: Changes and Continuities}

There are some important coincidences but also a number of significant differences between the results obtained in the surveys of 1996-1997 and 2006. With reference to the coincidences, the overall ethno-racial distribution of the Uruguayan population is similar in both surveys. In particular, we observe that: (a) whites are the overwhelming majority of the population; (b) Afro-descendants are the main ethno-racial minority; (c) there is a small percentage of Uruguayans with indigenous ancestry; and (d) people of Asian descent are a negligible minority. Second, most of those who acknowledged having black or indigenous ancestry also declared being of 
Table 9.6 Racial identification in Uruguay in 1996-1997 and 2006

\begin{tabular}{|c|c|c|}
\hline & 1996 & 2006 \\
\hline \multicolumn{3}{|l|}{ Non-Mestizos } \\
\hline White & 94.3 & 87.4 \\
\hline Black & 0.9 & 2.0 \\
\hline Indigenous & 0.2 & 0.4 \\
\hline Yellow & 0.4 & 0.1 \\
\hline \multicolumn{3}{|l|}{ Mestizos } \\
\hline White - Black & 0.5 & 6.3 \\
\hline White - Indigenous & 0.4 & 2.5 \\
\hline White - Other & 0.6 & $\mathrm{n} / \mathrm{a}$ \\
\hline Black - Indigenous & 0.0 & 0.2 \\
\hline Black - Other & 0.1 & $\mathrm{n} / \mathrm{a}$ \\
\hline Other combinations & 2.0 & 1.3 \\
\hline Total & 100 & 100 \\
\hline
\end{tabular}

Source: ECH 1996-1997 and ENHA 2006

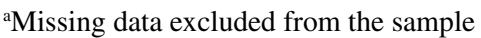

white descent. According to both surveys, thus, Uruguayan members of ethno-racial minorities seem to have been highly exposed to the process of racial mixing without, however, assimilating completely into the dominant Euro-descendant mainstream.

With reference to the disparities between both surveys, the 2006 survey indicates a much higher presence of ethnic minorities than the 1996 survey. First, the population identified as white only is 7 points lower in 2006 than in 1996 (94.3\% versus $87.4 \%$ ). In contrast, while in the ECH of 1996 less than $2 \%$ of the population identified as Afro-descendant, in 2006 this percentage was $9.1 \%$. The increase of the indigenous population was even more dramatic. While in 1996 only $0.8 \%$ of the population self-classified as indigenous (including mestizos with indigenous blood), $3.8 \%$ of Uruguayans declared being of indigenous descent in 2006 (Table 9.6).

It is interesting to note that the proportion of the population who identified as black or indigenous only did not change dramatically between 1996 and 2006. While $0.9 \%$ and $0.2 \%$ self-identified as blacks and indigenous in 1996, $2.0 \%$ and $0.4 \%$ declared being of black and indigenous descent only in 2006. Thus, it is sound to argue that the growth of Uruguayan ethnic minorities is mainly explained by the fact that the 2006 survey permitted subjects who would have self-classified as white in 1996 to indicate the possession of other ethno-racial backgrounds (Table 9.7).

\subsection{Searching for Explanations: Ethnic Revival, or Measurement Problems?}

How can we account for the huge increase of Uruguayan ethnic minorities in such a small period of time? Clearly, demographic factors cannot account for this trend. First, although Afro and indigenous descendants have higher fertility rates than 
Table 9.7 Percentage of Uruguayan Non-whites in 1996-1997 and 2006

\begin{tabular}{l|l|l|l}
\hline & 1996 & 2006 & Dif. \\
\hline Mixed Blacks & 0.8 & 7.1 & 6.3 \\
\hline Unmixed Blacks & 0.9 & 2.0 & 1.1 \\
\hline Mixed Indians & 0.6 & 3.4 & 2.8 \\
\hline Unmixed Indians & 0.2 & 0.4 & 0.2 \\
\hline Mestizos & 3.0 & $\mathrm{n} / \mathrm{a}$ & $\mathrm{n} / \mathrm{a}$ \\
\hline Other & 0.4 & $\mathrm{n} / \mathrm{a}$ & $\mathrm{n} / \mathrm{a}$ \\
\hline Total \% of Non-Whites & 5.7 & 12.6 & 7.3 \\
\hline
\end{tabular}

Sources: ECH 1996-1997 and ENHA 2006

whites, by no means these differences can account for the abovementioned growth of ethnic minorities during such a small period of time. Similarly, although it is possible that Uruguayans of white descent have had a higher predisposition to leave the country during the last three or four decades (in accordance with their higher levels of human and financial capital), it is possible to affirm that ethno-racial differences in migration rates were not that dramatic to explain the growth of ethnic minorities.

Our chapter proposes two alternative but complementary explanations that should be tested by future studies. Our main hypothesis is that the increase of ethnic minorities reflects the effects of having used two different race questions. In addition, the statistical growth of racial minorities might be partially explained by the revival of indigenous and Afro-descendant identities in recent times due to a variety of social processes.

\subsubsection{Questionnaire Design and Wording Effects}

While in the ECH of 1996 respondents were not allowed to choose more than one racial category (except those who self-classified as mestizos), in 2006 they were permitted to do so. As abovementioned, the ECH of 1996-1997 implemented a relatively rigid racial question: subjects were imposed to classify into only one racial category and only those who chose the 'mestizo' category (which is not a very popular term in the country) were offered the chance to indicate if they were of black, white, indigenous or yellow descent. Thus, it is reasonable to argue that many subjects who actually believed being of black or indigenous descent (and that might even identify as Afro or indigenous descendants in a variety of social instances) ended up classifying themselves as whites, in accordance with the belief that their main racial origin was white, the greater social legitimacy of the white category and/or the perception of being predominantly white from a phenotypic point of view.

In contrast, the 2006 questionnaire permitted to choose more than one category. Thus, it is plausible to argue that a significant number of those who declared being of Afro or indigenous descent in 2006: (a) only have remote black or indigenous ancestry (such as one great grandfather or grandfather); (b) would not self-classify as black 
or indigenous for other purposes or through other classificatory devices and/or (c) are not categorized as 'black' or 'indigenous' by others. In sum, it seems logical to hypothesize that many subjects who acknowledged being of indigenous or Afro descent in 2006 would have self-classified as whites in the 1996-1997 survey.

In second place, although both surveys collected racial data thorough selfclassificatory procedures, race was the central concept in the ECH of 1996 while descent was the key term used in the 2006 survey. Although the effects of these two terms on the process of racial classification have not been studied in the country yet, it seems sound to think that the 1996 question on race induced more individuals to classify as white, while the 2006 question on descent generated greater opportunities for acknowledging other ethnic backgrounds. Taking into account that whites constitute the dominant ethno-racial group in the country, it is logical to expect that only respondents who are constantly typified as non-whites in everyday life or that firmly identify themselves as such, picked up non-white categories in the ECH of 1996-1997. In other words, when forced to choose only one racial category, many subjects of mixed descent who might 'pass' as whites probably preferred to choose the white option over other categories.

The 2006 question, in contrast, simply asked about beliefs of descent. The term descent is more ambiguous than race and probably opens up greater possibilities of identifying as non-white. Specifically, taking into account the greater social status of the white category, it seems reasonable to argue that respondents will show greater resistance to identify as racially non-white than to acknowledge being of non-white descent partially. In addition, while the term race is usually associated with physical attributes such as skin colour and type of hair, the term descent does not necessarily imply this and is more associated with the ethnic characteristics of the family of origin. Thus, it might be the case that many respondents who see themselves as phenotypically white (and who, therefore, would have chosen the white category in 1996-1997), are also aware of having non-white members among their parents, grandparents or more distant ancestors.

\subsubsection{The Revitalization of Racial and Ethnic Roots in Uruguay}

Throughout the twentieth century, Uruguayan political and intellectual elites proudly distinguished the country from its Latin American neighbours for its presumed high levels of cultural homogeneity, its strong welfare state and the remarkable predominance of a European style of life. The 'Switzerland of America' (a metaphor invented by Luis Batlle Berres during his presidency in the early 1950s) perfectly synthesizes the way through which most Uruguayans have seen and compared themselves with other Latin Americans. It is not surprising, thus, that there exists a quite extended self-portrait of Uruguay as a racially homogenous country whose overwhelming majority is exclusively of European origin (Rodríguez 2006; Arocena and Aguiar 2007). 
However, since the last two decades the myths of racial homogeneity and equality of opportunities have been increasingly questioned by a variety of social movements, ethnic leaders, intellectuals and artists. First, the country witnessed the emergence of a variety of organizations whose members self-identified as indigenous descendants and questioned the traditional image of Uruguay as a society exclusively built by successive generations of European immigrants and descendants. At the same time, research done by local ethno-historians and biological anthropologists during the 1990s suggested that Uruguayans have a larger proportion of indigenous ancestry (especially from the Guarani communities) than that attributed by the dominant discourse (Sans et al. 1997; Bracco 2004). Finally, there are a growing number of literary and artistic works on indigenous topics (such as the genocide of the last indigenous communities that resided in the country or the indigenous influence on the Uruguayan nationality) and a greater debate on these topics in the media. As Teresa Porzecanski (2005) claims, the most remarkable consequence of these social phenomena has been the construction of a new national myth that questions the hegemonic discourses on Uruguayan identity, re-defines the country as a multicultural nation and puts a stronger emphasis on the similarities (rather than the differences) between the country and its Latin American neighbours.

In this new social atmosphere, there has also been an increasing recognition of the Afro-Uruguayan influence on the national culture and identity. Just to mention one example, the main subject of 2007 celebrations of the 'Day of the Patrimony' (which constitutes one of the most important rites of celebration of Uruguayan national identity), was the contributions of Afro-Uruguayan art and folklore to the country's identity. This remarkable political decision would hardly have occurred some decades ago.

The country has also witnessed an increasing academic interest in the past and contemporary situation of Afro-Uruguayans, probably as the combined result of the development of the social sciences in the country, the greater pressure exerted by Afro-Uruguayan organizations, the increasing concern on racial topics shown by international agencies such as the World Bank and the United Nations and the consolidation of a small but significant elite of black intellectuals and activists. Consequently, recent historiography has notably improved the knowledge on the main patterns of race relations during the slavery period (Frega et al. 2005; Montaño 2001; Bentancur and Aparicio 2006) and a number of works have illuminated a variety of critical aspects of contemporary Afro-Uruguayan identity (Porzecanski and Santos 2006; Rudolf and Maresca 2005) and racial inequality in the country (Beltrami 1998; Foster 2001; Bucheli and Cabella 2007). Finally, like its indigenous counterparts, Afro-descendant organizations have gained an increasing visibility among Uruguayans and exerted a greater pressure on state elites. In this sense, unlike local indigenous leaders (who principally fight for the acknowledgement of the indigenous contributions to the national identity), the main concern of AfroUruguayan leaders is the official recognition of the existence of significant levels of racial inequality and the implementation of a number of public policies that alleviate this situation. 
In sum, the increasing social legitimacy of the neo-indigenous myths and the greater visibility and pressure exerted by Afro-descendant organizations have contributed to the redefinition of the Uruguayan collective identity. Our hypothesis is that although this redefinition has not abolished the myths of racial homogeneity and equality, they have generated greater incentives to identify as non-white in surveys and other social instances. Thus, it is possible that the statistical growth of ethnic minorities between 1996 and 2006 not only responds to technical issues such as the abovementioned 'wording effects' but also to this general and significant social process.

\subsection{Discussion: Racial Inequality and Racial Classification}

To conclude this chapter, we would like to analyze a variety of socioeconomic indicators by race, based again on the Permanent Household Surveys of 1996-1997 and 2006. The main goal is to show the existence of a significant socioeconomic gap between Afro-descendants and whites, regardless of the particular method of racial classification used. ${ }^{10}$ The evidence, thus, strongly questions the national myths of racial democracy and equality of opportunities that still prevail among Uruguayans.

Although between 1996 and 2006, both Afro-descendants and whites improved their educational levels, both surveys show that Afro-descendants have remarkably lower degrees of educational attainment (see Table 9.8). Afro-descendants have fewer years of schooling and much lower enrolment rates at the secondary and tertiary levels. The small proportion of Afro-descendant students in tertiary organizations is particularly remarkable. Both in 1996-1997 and 2006, the proportion of whites who were enrolled at these organizations almost doubled up that of Afro-descendants.

Regarding labour market indicators, Afro-descendants have greater participation and employment rates but they are also more likely to be unemployed. Afrodescendants' greater participation rates are explained by the fact that they usually entry the labour market before and exit it after their white counterparts do so. This trend is in line with Afro-descendants' greater secondary dropout rates and their greater difficulties to live from retirement funds. This, in turn, is associated with the fact that Afro-descendants are less likely to be formally employed (Bucheli and Cabella 2007). Finally, it must be noted that Afro-descendants are more likely to work at blue collar occupations. In particular, Afro-descendant men and women are overrepresented among construction workers and domestic employees respectively.

\footnotetext{
${ }^{10}$ Unfortunately, the small proportion of subjects who identified as Indigenous in 1996 impedes to analyze the socio-economic profile of this ethnic minority for that year. According to the 2006 survey, those who declared being of indigenous descent are in between Afro-descendants and whites in terms of socio-economic well-being, but closer to the latter group (Bucheli and Cabella 2007).
} 
Table 9.8 Basic socioeconomic indicators of the Uruguayan population by race (1996 and 2006)

\begin{tabular}{l|r|r|r|r|r|r|r}
\hline & \multicolumn{3}{l}{ Afro-descendants } & \multicolumn{2}{l}{ Whites } & \multicolumn{2}{l}{ Total } \\
\cline { 2 - 8 } & 1996 & 2006 & 1996 & 2006 & 1996 & 2006 \\
\hline $\begin{array}{l}\text { Education } \\
\text { Mean years of schooling (25 years or more) }\end{array}$ & 6.8 & 7.3 & 8.1 & 8.8 & 8.0 & 8.7 \\
\hline $\begin{array}{l}\text { Enrolled students at secondary stage } \\
\text { (14-17 years) }\end{array}$ & 57.6 & 68.4 & 75.0 & 80.5 & 73.7 & 79.1 \\
\hline $\begin{array}{l}\text { Enrolled students at tertiary stage } \\
\text { (18-24 years) }\end{array}$ & 14.1 & 22.3 & 31.9 & 40.7 & 30.9 & 38.9 \\
\hline $\begin{array}{l}\text { Labour market } \\
\text { Participation rate }\end{array}$ & 65.9 & 66.1 & 57.5 & 60.1 & 57.9 & 60.8 \\
\hline Employment rate & 54.7 & 56.8 & 50.9 & 53.8 & 51.1 & 54.1 \\
\hline Unemployment rate & 17.0 & 14.1 & 11.4 & 10.5 & 11.7 & 10.9 \\
\hline Economic well-being & & & & & & \\
\hline Poverty rate & 44.1 & 50.1 & 21.9 & 24.4 & 23.5 & 27.0 \\
\hline
\end{tabular}

Source: ECH 1996-1997. ENHA 2006

Overall, the different performance of Afro-descendants and whites at the educational and labour markets leads to significant racial disparities in a variety of indicators of material welfare. For instance, we can observe in Table 9.8 that in 1996 and 2006 the proportion of Afro-descendants living below the poverty line doubled up that of whites.

Although we do not dispute that racial inequality is severe in the country, we believe that the questions on race implemented by the 1996 and 2006 surveys (which are based exclusively on self-classificatory procedures) do not permit to estimate the degrees of racial inequality with complete accuracy. People are not usually discriminated because of their perceived descent or race but mainly because of their skin colour and other physical markers. In terms of discrimination, thus, it seems more important to 'look like' than to 'identify as' Afro-descendant. Therefore, the use of racial data based exclusively on self-classificatory procedures impedes the analyst to know whether those who self-identify as Afro or indigenous descendants are seen as members of these groups by others.

Another potential problem of analyzing racial inequality in Uruguay based on self-classification is that upper or middle-class members of unprivileged minorities could have a greater tendency to 'whiten' themselves than those who remain at the bottom of the social pyramid, in accordance with the trend observed for other Latin American countries (Harris 1964; Wade 1995; Wood 1991). If this was the case, analysts are exposed to the risk of confounding the true effects of racial membership on socioeconomic status with those of socioeconomic status on race (i.e., racial classification).

Taking into account these considerations and following Telles and Lim's seminal work on Brazil (1998), we believe that it is sound to measure racial inequality in Uruguay through a race variable that reflects the pollsters' rather than the interviewees' classifications or, alternatively, through a combination of both methods of clas- 
sification. Questions based on self-classificatory procedures, in turn, might be more effective to analyze phenomena related to identificational matters such as ethnic revival/assimilation.

Open Access This chapter is distributed under the terms of the Creative Commons Attribution Noncommercial License, which permits any noncommercial use, distribution, and reproduction in any medium, provided the original author(s) and source are credited.

\section{References}

Arocena, F., \& Aguiar, S. (2007). Multiculturalismo en Uruguay. Montevideo: Ediciones Trilce, $232 \mathrm{p}$.

Beltrami, M. (1998). Encuesta continua de hogares: Módulo de raza. Principales resultados (p. 26). Montevideo: Instituto Nacional de Estadística.

Bentancur, A., \& Aparicio, F. (2006). Amos y esclavos en el Río de la Plata (p. 336). Montevideo: Planeta.

Bracco, D. (2004). Charrúas, guenoas y guaraníes. Interacción y destrucción: Indígenas en el Río de la Plata (p. 126). Montevideo: Linardi y Risso.

Bucheli, M., \& Cabella, W. (2007). El perfil demográfico y socioeconómico de la población uruguaya según su ascendencia racial (p. 62). Montevideo: Instituto Nacional de Estatística. http://www.ine.gub.uy/enha2006/Informe\%20final\%20raza.pdf

Cabrera, L., \& Curbelo, M. C. (1988). Aspectos sociodemográficos de la influencia guaraní en el sur de la antigua Banda Oriental. In Anais do VII Simpósio Nacional de Estudos Missioneiros (pp. 117-145). Santa Rosa: Faculdade de Filosofia e Letras Dom Bosco.

Foster, J. (2001). El racismo y la reproducción de la pobreza entre los afrouruguayos. CLAEH: Serie Investigaciones, 69, 5-58.

Frega, A., Borucki, A., Chagas, C., \& Stalla, N. (2005). Esclavitud y abolición en el Río de la Plata en tiempos de revolución y república. In Memorias del Simposio La ruta del esclavo en el Río de la Plata: su historia y sus consecuencias (pp. 17-149). Montevideo: UNESCO.

Harris, M. (1964). Patterns of race in the Americas (p. 154). New York: Walker and Company.

Instituto Nacional de Estadística (INE). (1998). Encuesta Continua de Hogares. Módulo de Raza 1996 - 1997. Apreciaciones sobre registros y apareo de archivos (p. 28). Montevideo: Unpublished Manuscript.

Montaño, O. (2001), Yeninyanya (Umkhonto II): Historia de los afrouruguayos (p. 221). Montevideo: Mundo Afro.

Pellegrino, A. (2003). Caracterización demográfica del Uruguay. In UNFPA-UdelaR (p. 40). Montevideo: UNFPA.

Porzecanski, T. (2005). Nuevos imaginarios de la identidad uruguaya: Neoindigenismo y ejemplaridad. In G. Caetano (Ed.), 20 años de democracia en Uruguay 1985-2005, miradas múltiples (pp. 407-426). Montevideo: Taurus.

Porzecanski, T., \& Santos, B. (2006). Historias de exclusión: Afrodescendientes en el Uruguay (p. 139). Montevideo: Linardi y Risso.

Rodríguez, R. (2006). Mbundo, Malungo a Mundele: Historia del movimiento afrouruguayo y sus alternativas de desarrollo (p. 247). Montevideo: Rosebud.

Rudolf, S., \& Maresca, I. (2005). Incorporación de la variable etnia/raza en las estadísticas vitales en el Uruguay (p. 69). Montevideo: OPS.

Sans, M., Salsano, F., \& Chakraborty, R. (1997). Historical genetics in Uruguay: Estimates of biological origins and their problems. Human Biology, 69(2), 161-170. 
Telles, E., \& Lim, N. (1998). Does it matter who answers the race question? Racial classification and income inequality in Brazil. Demography, 35(4), 465-474.

Urrea, F. (2005). La población afrodescendiente en Colombia. In CEPAL (Ed.), Pueblos indígenas y afrodescendientes de América Latina y el Caribe: Información sociodemográfica para políticas y programas (pp. 219-246). Santiago de Chile: CEPAL.

Wade, P. (1995). Blackness and race mixture: The dynamics of racial identity in Colombia (p. 415). Baltimore: Johns Hopkins University Press.

Wood, C. (1991). Categorias censitarias e classificaçoes subjetivas de raça no Brasil. In P. A. Lovell (Ed.), Desigualdade racial no Brasil contemporáneo (pp. 93-111). Belo Horizonte: UFMG/CEDEPLAR. 